\title{
The prognostic significance of KRAS and $B R A F$ mutation status in Korean colorectal cancer patients
}

\author{
Daeyoun David Won', Jae Im Lee ${ }^{2}$, In Kyu Lee', Seong-Taek Oh², Eun Sun Jung ${ }^{3}$ and Sung Hak Lee ${ }^{3^{*}}$ (D)
}

\begin{abstract}
Background: BRAF and KRAS mutations are well-established biomarkers in anti-EGFR therapy. However, the prognostic significance of these mutations is still being examined. We determined the prognostic value of BRAF and KRAS mutations in Korean colorectal cancer (CRC) patients.

Methods: From July 2010 to September 2013, 1096 patients who underwent surgery for CRC at Seoul St. Mary's Hospital were included in the analysis. Resected specimens were examined for BRAF, KRAS, and microsatellite instability (MSI) status. All data were reviewed retrospectively.

Results: Among 1096 patients, 401 (36.7\%) had KRAS mutations and 44 (4.0\%) had BRAF mutations. Of 83 patients, 77 (92.8\%) had microsatellite stable (MSS) or MSI low (MSI-L) status while 6 (7.2\%) patients had MSI high (MSI-H) status. Patients with BRAF mutation demonstrated a worse disease-free survival (DFS, HR 1.990, Cl 1.080-3.660, $P=0$. 02) and overall survival (OS, HR 3.470, $\mathrm{Cl} 1.900-6.330, P<0.0001)$. Regarding KRAS status, no significant difference was noted in DFS $(P=0.0548)$ or OS $(P=0.107)$. Comparing the MSS/MSI-L and MSI-H groups there were no significant differences in either DFS $(P=0.294)$ or OS $(P=0.557)$.

Conclusions: BRAF mutation, rather than KRAS, was a significant prognostic factor in Korean CRC patients at both early and advanced stages. The subgroup analysis for MSI did not show significant differences in clinical outcome. BRAF should be included in future larger prospective biomarker studies on CRC.
\end{abstract}

Keywords: BRAF mutation, KRAS mutation, MSI, Colorectal cancer

\section{Background}

Colorectal cancer (CRC) is the second most common cancer in females and the third most common cancer in males worldwide [1]. It is one of the most rapidly growing cancers in Korea with an annual increase (from 1999 to 2009) of $6.2 \%$ in men and $6.8 \%$ in women [2]. Despite advances in CRC treatment and a decline in the mortality rate over the past few decades, CRC remains the second most common cause of cancer death in females and third common cause of cancer death in males [3].

Considerable advances have been made in the characterization of genetic alterations in CRC in support of genome-wide profiling. The Cancer Genome Atlas

\footnotetext{
* Correspondence: hakjjang@catholic.ac.kr

${ }^{3}$ Department of Hospital Pathology, Seoul St. Mary's Hospital, College of Medicine, The Catholic University of Korea, 222, Banpo-daero, Seocho-gu, Seoul 06591, Republic of Korea

Full list of author information is available at the end of the article
}

Network accomplished the largest comprehensive molecular analysis of CRC to date [4]. Based on somatic mutation rates, colorectal adenocarcinomas were classified as hypermutated or non-hypermutated. The hypermutated group had somatic mutations caused by high microsatellite instability (MSI), usually with $M L H 1$ silencing or mismatch repair gene mutations. $B R A F$ and $A C V R 2 A$ mutations were enriched in hypermutated samples. However, the non-hypermutated group had frequent gene copy number alterations. In addition, APC, TP53, KRAS, and PIK3CA mutations were observed. These are characteristic of chromosomal instability [4].

The v-Ki-ras2 Kirsten rat sarcoma viral oncogene homolog (KRAS), a member of the Ras subfamily, is a proto-oncogene that encodes a $21 \mathrm{kDa}$ GTPase located on the short arm of chromosome 12 [5]. The RAS protein activates several downstream signaling cascades 
such as the mitogen-activated protein kinase (MAPK) and PI3K pathways that regulate multiple cellular functions including cell proliferation, differentiation, motility, survival, and intracellular trafficking [6]. KRAS is considered a key downstream component of the epidermal growth factor receptor (EGFR) signaling pathway; therefore, mutations of the gene result in a constitutive activation of the EGFR signaling cascade [5]. KRAS mutations are identified in $30-50 \%$ of CRCs and are usually point mutations that occur in codons 12 and 13, less often in codon 61 , and very infrequently at other sites such as codons $59,146,19$, or $20[5,7]$. KRAS mutation is a wellestablished biomarker that predicts resistance to therapy using anti-EGFR monoclonal antibodies in metastatic CRC [8]. However, the prognostic value of KRAS mutations in CRC is controversial. Some studies revealed that KRAS mutations are associated with poorer prognosis, while others have reported no association [9-12].

The v-Raf murine sarcoma viral oncogene homolog B1 (BRAF) is a serine/threonine kinase that plays a part in cell proliferation, survival, and differentiation; [13]. Activating $B R A F$ mutations have been detected in various malignant tumors such as melanoma, papillary thyroid cancer, CRC, ovarian cancer, and hairy cell leukemia [13-15]. In CRC, $B R A F$ mutations are reported in 4.7 to $20 \%$ of tumors [13, 16]. Usually, BRAF and KRAS mutations are usually mutually exclusive [17]. The most common $B R A F$ mutation, found in over $90 \%$ of human cancers, is a glutamic acid for valine substitution at codon 600 in exon 15 (V600E), leading to constitutive activation of the MAPK pathway [18]. The predictive role of $B R A F$ mutation in response to anti-EGFR therapy remains uncertain; however, previous studies found that BRAF mutations are associated with an adverse clinical outcome, especially in advanced stage CRC $[16,19,20]$.

In the present study, we comprehensively investigated $K R A S$ and BRAF mutation status in Korean CRC patients. In addition, we analyzed the relationship of KRAS and $B R A F$ mutation with MSI status.

\section{Methods}

\section{Patients and treatment}

We retrospectively reviewed specimens from 1096 consecutive patients who underwent surgical CRC resection at Seoul St. Mary's Hospital, The Catholic University of Korea, between July 2010 and September 2013. CRC cases with tissue blocks eligible for the KRAS and BRAF mutation testing were included in this study. Two gastrointestinal pathologists reviewed and classified CRC slides according to World Health Organization classification. Clinicopathological parameters were obtained from patient medical records and pathology reports at our institution. Adjuvant chemotherapy was recommended to high-risk (cancer obstruction, perforation, poor differentiation, or lymphovascular/perineural invasion) stage II or stage III CRC patients. According to the BRAF and KRAS mutational status, patients were offered targeted agents as an adjunct to systemic chemotherapy. However, due to insurance coverage issues, only 3 patients received antiEGFR and only 12 received anti-vascular endothelial growth factor therapy during the study period. Approval for this study was acquired from the Institutional Review Board of the Catholic University of Korea, College of Medicine (KC16RISI0011).

\section{DNA isolation and analysis of KRAS and BRAF mutations}

For DNA isolation, $10-\mu \mathrm{m}$-thick sections from formalinfixed paraffin-embedded (FFPE) tissue samples were used for each case. Hematoxylin \& eosin sections were used as a reference and the largest tumor area was scraped off with a scalpel under a dissecting microscope. Genomic DNA was extracted using the QIAamp DNA FFPE tissue kit (Qiagen Inc., Valencia, CA) according to the manufacturer's recommendations. Sanger sequencing was performed using an ABI 3730 automated sequencer (Applied Biosystems, Inc., Foster City, CA), to detect the presence of KRAS exon 2 mutations with previously reported primers [21]. Exon 15 of the BRAF gene was amplified by polymerase chain reaction (PCR) using the following forward primer (5'AATGCTTGCTCTGATAGGAAAAT-3') and reverse primer (5'-TAATCAGTGGAAAAATAGCCTC-3'), resulting in a 209 base pair PCR product. The resultant PCR products were purified using the QIAquick PCR Purification Kit (Qiagen Inc., Valencia, CA) and the appropriate protocol on the QIAcube robotic workstation. Each chromatogram was visually inspected for abnormalities.

\section{MSI analysis}

Five microsatellite markers (BAT-25, BAT-26, D2S123, D5S346, and D17S250) recommended by a National Cancer Institute workshop on MSI determined the microsatellite status [22]. PCR analyses were performed and the shift of PCR products from tumor DNA was compared to normal DNA. Tumors with at least 2 of the 5 microsatellite markers displaying shifted alleles were classified as MSI-H, whereas tumors with only 1 marker exhibiting a novel band were classified as MSI-L. Samples in which all microsatellite markers displayed the same patterns in tumor and normal tissues were classified as MSS; subsequently, MSS and MSI-L tumors were grouped for analyses based on genetic implications [22].

\section{Statistical analysis}

Continuous variables were analyzed by student's $\mathrm{t}$ or Mann-Whitney $U$ test, expressed as the mean \pm SD. For categorical variables, $X^{2}$-test analysis or Fisher's exact test was used. Survival analysis was performed by the Kaplan-Meier method. Statistical analysis was performed with SPSS software version 18 (SPSS Inc., Chicago, IL) 
and the $\mathrm{R}$ programing language ( $\mathrm{R}$ Core Team 2015, A language and environment for statistical computing, $\mathrm{R}$ Foundation for Statistical Computing, Vienna, Austria, URL http://www.r-project.org/). A P-value of $<0.05$ was considered significant.

\section{Results \\ Patient characteristics according to KRAS or BRAF mutation status}

The present study included 1092 patients with $K R A S$ and 1096 patients with $B R A F$ mutation data. Tables 1 and 2 summarize the clinicopathological characteristics of patients. A total of 401 patients (36.7\%) had KRAS mutations. KRAS mutated CRCs were significantly associated with females $(45.1 \%$ vs $34.6 \%$ with wild-type $K R A S$; $P=0.001)$, right sided tumors $(32.4 \%$ vs $21.0 \% ; P<0.001)$, higher $\mathrm{T}$ stage (T4, $15.3 \%$ vs $11.0 \% ; P=0.005$ ), well to moderate differentiation ( $98.7 \%$ vs $94.7 \% ; P=0.002)$, and mucinous adenocarcinoma $(9.2 \%$ vs $4.9 \% ; P=0.002)$. $B R A F$ mutations were detected in 44 patients $(4.0 \%)$. The proportion of $B R A F$ mutation was higher in tumors located in the right colon $(56.8 \%$ vs $23.9 \%$ with wild-type $B R A F ; P=0.001$ ), with an advanced tumor stage (T4, $29.5 \%$ vs $11.9 \% ; P=0.005$ ), with lymph node metastasis (N2, 38.6\% vs $20.5 \% ; P=0.015)$, and with lymphatic invasion (65.9\% vs $44.0 \%$; $P=0.007$ ). BRAF mutated tumors trended toward poorly differentiated histology $(10.0 \%$ vs $3.6 \%, P=0.099)$ and an infiltrative growth pattern $(22.7 \%$ vs $15.2 \% ; P=0.065)$ compared to wild-type $B R A F$ tumors, but these were not statistically significant. In addition, gender distribution according to KRAS mutation status did not differ significantly, showing a bimodal distribution pattern along the colorectum. Distributions with respect to tumor sites for all three tumor subgroups (KRAS-mutated, $B R A F$-mutated and null CRCs), stratified for gender, are shown in Fig. 1a-c.

\section{Mutation frequencies in KRAS and BRAF}

A $K R A S$ codon 12 mutation was observed in 296 patients. A KRAS codon 13 mutation was observed in 98 patients. Seven other patients had either KRAS codon 14 or 30 mutations. The most frequent amino acid change was Gly12Asp, which accounted for $36.9 \%$ of KRAS mutations (148/401). The second most frequent mutation was Gly13Asp $(24.2 \%, 97 / 401)$, and the third was Gly12Val (21.9\%, 88/401). Table 3 lists detailed nucleotide and codon changes. Regarding BRAF mutations, Val600Glu in exon 15 showed the highest frequency $(97.7 \%, 43 / 44)$ (Table 4$)$. In addition, our data revealed $3 K R A S$ and $B R A F$ co-mutated cases. Among these 3 cases, 2 had Gly13Asp KRAS mutations, 1 had a Gly12Asp mutation, and all BRAF mutations were Val600Glu. All 3 cases had lymph node metastasis and were included in stage III; however, no recurrences or deaths were observed.

\section{Impact of KRAS and BRAF mutations on DFS and OS}

After a median follow-up of 29 months, the 5-year disease free survival rate of the study population was $81 \%$. There was no significant difference according to KRAS mutation status; however, DFS trended toward being shorter in patients with $K R A S$ mutations than those with wild-type KRAS $(P=0.0548)$. DFS was also significantly worse in patients with $B R A F$ mutated cancers compared to wildtype $B R A F$ by both univariate (HR $1.98, P=0.0252)$ and multivariate analyses (HR 2.222) (Fig. 2a and b).

Regarding OS, the 5-year rate was $80 \%$. No significant difference in OS according to KRAS mutation status was revealed $(P=0.108)$. OS was significantly shorter for patients with $B R A F$ mutations than those with wild-type $B R A F$ by univariate analysis (HR 3.46, 95\% CI 1.9-6.3, $P<0.0001$ ). In the multivariate analysis, $B R A F$ mutations also had a negative impact on OS (HR 4.037, 95\% CI 2.172-7.506, $P<0.0001$ ) (Fig. 2c and d). In addition, we assessed whether the detrimental effect of KRAS mutations was different according to mutation subtypes and showed that there were no significant differences in DFS $(P=0.931)$ or OS $(P=0.816)$ (Additional file 1: Fig. S1A and B).

Considering KRAS and BRAF mutations together, DFS and $O S$ were significantly more favorable in patients with wild-type $K R A S$ and $B R A F$ compared to patients with mutations in both genes (HR 1.540, 95\% CI 1.140-2.080, $P=0.0049)$ and OS (HR 1.860, 95\% CI 1.280-2.720, $P=0.0010)$ (Fig. 3a and b).

\section{Subgroup analysis on DFS and OS by stage}

In stage I colorectal cancer, $B R A F$ mutations had a negative impact on both DFS (HR 3.936, 95\% CI 2.120-7.306, $P<0.0001)$ and OS (HR 4.037, 95\% CI 2.172-7.506, $P<0.0001)$. However, KRAS mutations did not demonstrate a significant effect on DFS (HR 1.539, 95\% CI $1.039-2.279, P=0.112$ ) or OS (HR 1.555, 95\% CI 1.0482.305, $P=0.107$ ) (Fig. $4 \mathrm{a}$ and b). In stage II and III colorectal cancer, $B R A F$ mutations had a negative impact on DFS (HR 1.940, 95\% CI 1.050-3.570, $P=0.0322$ ) and OS (HR 3.320, 95\% CI 1.820-6.070, $P<0.0001$ ). However, KRAS mutations did not demonstrate a significant effect on DFS (HR 1.250, 95\% CI 0.910-1.720, $P=0.169$ ) or OS (HR 1.400, 95\% CI 0.950-2.070, $P=0.0917$ ) (Fig. 4c and d). In stage IV CRC, BRAF mutation status did not show a significant effect on DFS (HR 1.180, 95\% CI 0.290-4.870, $P=0.82)$ or OS (HR 2.660, 95\% CI 0.950-7.450, $P=0.0548)$. KRAS mutation status also did not demonstrate a significant effect on DFS (HR 1.140, 95\% CI $0.670-1.930, P=0.627)$ or OS $(1.410,95 \%$ CI $0.790-$ 2.520, $P=0.247$ ) (Fig. 4e and $\mathrm{f}$ ).

\section{Patient characteristics according to MSI status}

MSI test data were available in 83 patients. Univariate analysis was performed according to clinicopathologic factors 
Table 1 Clinicopathologic characteristics according to KRAS mutation status

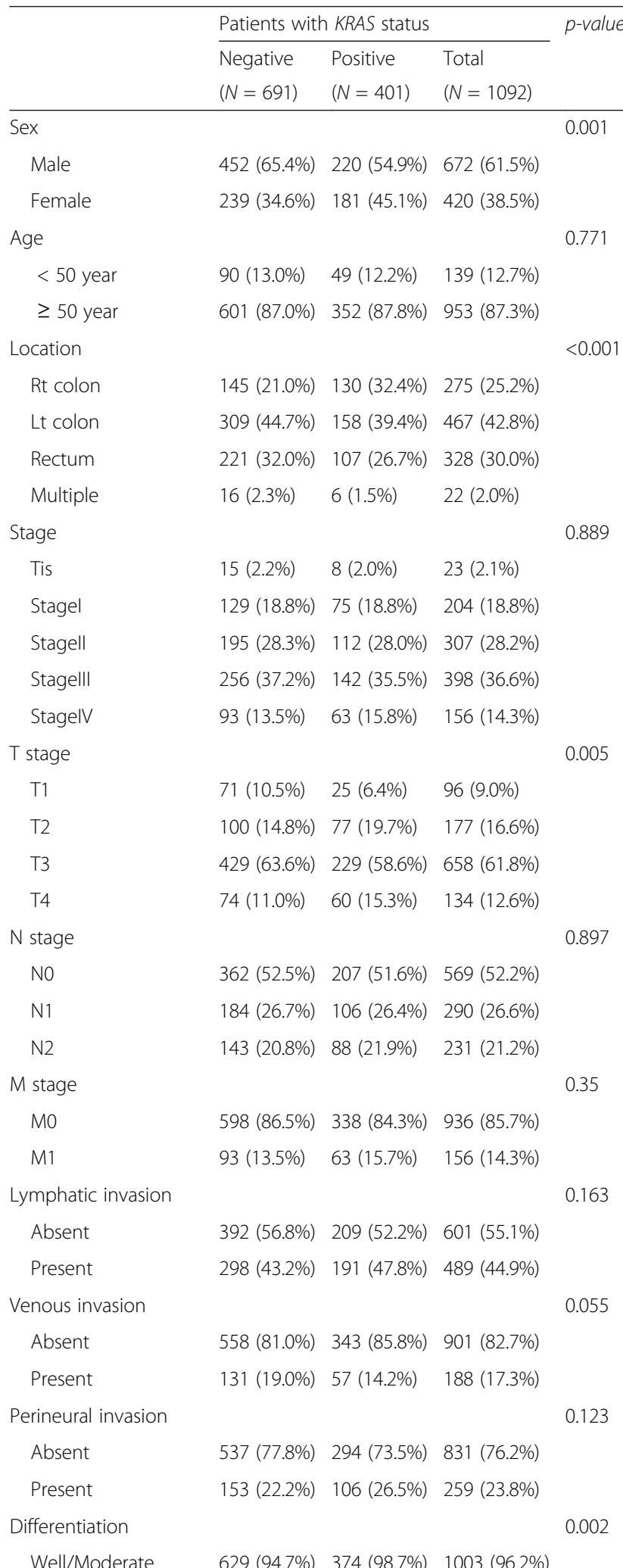

Table 1 Clinicopathologic characteristics according to KRAS mutation status (Continued)

\begin{tabular}{lllll}
\hline Poor & $35(5.3 \%)$ & $5(1.3 \%)$ & $40(3.8 \%)$ & \\
Histology & & & & 0.008 \\
$\begin{array}{l}\text { Non-mucinous } \\
\text { adenocarcinoma }\end{array}$ & $657(95.1 \%)$ & $364(90.8 \%)$ & $1021(93.5 \%)$ & \\
$\begin{array}{l}\text { Mucinous } \\
\text { adenocarcinoma }\end{array}$ & $34(4.9 \%)$ & $37(9.2 \%)$ & $71(6.5 \%)$ & \\
Recur & & & & 0.143 \\
Recur & $593(85.8 \%)$ & $330(82.3 \%)$ & $923(84.5 \%)$ & \\
Non-recur & $98(14.2 \%)$ & $71(17.7 \%)$ & $169(15.5 \%)$ & \\
Expire & & & & 0.219 \\
Expire & $629(91.0 \%)$ & $355(88.5 \%)$ & $984(90.1 \%)$ & \\
Non- Expire & $62(9.0 \%)$ & $46(11.5 \%)$ & $108(9.9 \%)$ & \\
Neoadjuvant Tx & & & & 0.217 \\
No & $605(87.6 \%)$ & $364(90.8 \%)$ & $969(88.7 \%)$ & \\
CTx & $31(4.5 \%)$ & $10(2.5 \%)$ & $41(3.8 \%)$ & \\
RT & $2(0.3 \%)$ & $0(0.0 \%)$ & $2(0.2 \%)$ & \\
CCRT & $53(7.7 \%)$ & $27(6.7 \%)$ & $80(7.3 \%)$ & \\
\hline
\end{tabular}

and MSI status. A significant difference was noted in CRC location $(P=0.037)$. MSH-H had a higher frequency in colon cancers of the right side (66.7\% vs $23.4 \%)$. MSS/ MSI-L CRCs were more prevalent on the left $(50.6 \%$ vs 16.7\%). Regarding histological differentiation, a significant difference was noted $(P=0.012)$. MSI-H had higher number of poorly differentiated CRC (1.4\% vs $25.0 \%)$. Mucinous CRC was observed more frequently in the MSI$\mathrm{H}$ group $(6.5 \%$ vs $83.3 \%, P<0.001)$ (Table 5$)$.

\section{Impact of MSI status on DFS and OS}

We compared DFS and OS between MSS/MSI-L and MSI$\mathrm{H}$ groups to evaluate the value of MSI status as a prognostic marker. MSI status did not show a significant difference in DFS $(P=0.294)$ or OS $(P=0.557)$ (Fig. $5 \mathrm{a}$ and b).

\section{Discussion}

In this study, we evaluated KRAS and BRAF mutational status in 1096 Korean CRC patients using direct sequencing. To the best of our knowledge, our study is one of the first to report the prognostic significance of KRAS and BRAF mutation status in the Korean CRC population. A major strength of this study was the comprehensive subgroup analysis done according to CRC stage and MSI status with a relatively large sample size.

We uncovered an overall KRAS mutation rate of $36.7 \%$ in colorectal cancers, which was consistent with most previous reports [23-26]. We also found that proximal CRCs had a higher percentage of KRAS mutations compared to those at a distal location. This finding is in line with a recent study by Rosty et al. [27]. Furthermore, we 
Table 2 Clinicopathologic characteristics according to BRAF mutation status

\begin{tabular}{|c|c|c|c|c|}
\hline & \multicolumn{3}{|c|}{ Patients with BRAF status } & \multirow[t]{3}{*}{$p$-value } \\
\hline & Negative & Positive & Total & \\
\hline & $(N=1052)$ & $(N=44)$ & $(N=1096)$ & \\
\hline Sex & & & & 0.149 \\
\hline Male & $652(62.0 \%)$ & $22(50.0 \%)$ & $674(61.5 \%)$ & \\
\hline Female & $400(38.0 \%)$ & $22(50.0 \%)$ & $422(38.5 \%)$ & \\
\hline Age & & & & 0.375 \\
\hline$<50$ year & $131(12.5 \%)$ & $8(18.2 \%)$ & $139(12.7 \%)$ & \\
\hline$\geq 50$ year & $921(87.5 \%)$ & $36(81.8 \%)$ & 957 (87.3\%) & \\
\hline Location & & & & 0 \\
\hline Rt colon & $252(24.0 \%)$ & $25(56.8 \%)$ & $277(25.3 \%)$ & \\
\hline Lt colon & $455(43.3 \%)$ & $14(31.8 \%)$ & $469(42.8 \%)$ & \\
\hline Rectum & $324(30.8 \%)$ & $4(9.1 \%)$ & $328(29.9 \%)$ & \\
\hline Multiple & $21(2.0 \%)$ & $1(2.3 \%)$ & $22(2.0 \%)$ & \\
\hline Stage & & & & 0.226 \\
\hline Tis & $23(2.2 \%)$ & $0(0.0 \%)$ & $23(2.1 \%)$ & \\
\hline Stagel & 205 (19.6\%) & $5(11.4 \%)$ & $210(19.2 \%)$ & \\
\hline Stagell & $323(30.9 \%)$ & $12(27.3 \%)$ & $335(30.7 \%)$ & \\
\hline Stagelll & $496(47.4 \%)$ & $27(61.4 \%)$ & $523(47.9 \%)$ & \\
\hline T stage & & & & 0.006 \\
\hline $\mathrm{T} 1$ & $93(9.1 \%)$ & $3(6.8 \%)$ & $96(9.0 \%)$ & \\
\hline $\mathrm{T} 2$ & $173(16.9 \%)$ & $4(9.1 \%)$ & $177(16.6 \%)$ & \\
\hline T3 & $637(62.1 \%)$ & $24(54.5 \%)$ & $661(61.8 \%)$ & \\
\hline T4 & $122(11.9 \%)$ & $13(29.5 \%)$ & $135(12.6 \%)$ & \\
\hline N stage & & & & 0.015 \\
\hline NO & $553(52.7 \%)$ & 17 (38.6\%) & $570(52.1 \%)$ & \\
\hline $\mathrm{N} 1$ & $282(26.9 \%)$ & $10(22.7 \%)$ & $292(26.7 \%)$ & \\
\hline N2 & $215(20.5 \%)$ & 17 (38.6\%) & $232(21.2 \%)$ & \\
\hline \multicolumn{5}{|l|}{ M stage } \\
\hline MO & $3(75.0 \%)$ & $0(0.0 \%)$ & $3(75.0 \%)$ & \\
\hline M1 & $1(25.0 \%)$ & $0(0.0 \%)$ & $1(25.0 \%)$ & \\
\hline Lymphatic invasion & & & & 0.007 \\
\hline Absent & $588(56.0 \%)$ & 15 (34.1\%) & $603(55.1 \%)$ & \\
\hline Present & $462(44.0 \%)$ & $29(65.9 \%)$ & 491 (44.9\%) & \\
\hline Venous invasion & & & & 0.109 \\
\hline Absent & $873(83.2 \%)$ & $32(72.7 \%)$ & 905 (82.8\%) & \\
\hline Present & $176(16.8 \%)$ & $12(27.3 \%)$ & $188(17.2 \%)$ & \\
\hline Perineural invasion & & & & 0.451 \\
\hline Absent & 804 (76.6\%) & 31 (70.5\%) & 835 (76.3\%) & \\
\hline Present & $246(23.4 \%)$ & $13(29.5 \%)$ & $259(23.7 \%)$ & \\
\hline Differentiation & & & & 0.081 \\
\hline Well & $96(9.5 \%)$ & $2(5.0 \%)$ & $98(9.4 \%)$ & \\
\hline Moderate & 875 (86.9\%) & $34(85.0 \%)$ & 909 (86.8\%) & \\
\hline
\end{tabular}

Table 2 Clinicopathologic characteristics according to BRAF mutation status (Continued)

\begin{tabular}{lllll}
\hline Poor & $36(3.6 \%)$ & $4(10.0 \%)$ & $40(3.8 \%)$ & 0.302 \\
Histology & & & & \\
$\begin{array}{l}\text { Non-mucinous } \\
\text { adenocarcinoma }\end{array}$ & $986(93.7 \%)$ & $39(88.6 \%)$ & $1025(93.5 \%)$ & \\
$\begin{array}{l}\text { Mucinous } \\
\text { adenocarcinoma }\end{array}$ & $66(6.3 \%)$ & $5(11.4 \%)$ & $71(6.5 \%)$ & \\
Recur & & & & 0.113 \\
Recur & $894(85.0 \%)$ & $33(75.0 \%)$ & $927(84.6 \%)$ & 0 \\
Non-recur & $158(15.0 \%)$ & $11(25.0 \%)$ & $169(15.4 \%)$ & \\
Expire & & & & \\
Expire & $956(90.9 \%)$ & $32(72.7 \%)$ & $988(90.1 \%)$ & \\
Non-Expire & $96(9.1 \%)$ & $12(27.3 \%)$ & $108(9.9 \%)$ & \\
Neoadjuvant Tx & & & & \\
No & $929(88.3 \%)$ & $41(93.2 \%)$ & $970(88.5 \%)$ & \\
CTx & $40(3.8 \%)$ & $2(4.5 \%)$ & $42(3.8 \%)$ & \\
RT & $2(0.2 \%)$ & $0(0.0 \%)$ & $2(0.2 \%)$ & \\
CCRT & $81(7.7 \%)$ & $1(2.3 \%)$ & $82(7.5 \%)$ & \\
\hline & & & & \\
\hline
\end{tabular}

found that the frequencies of KRAS mutations showed a bimodal distribution pattern along the colorectum. Consistent with previous studies, our data indicated that the frequency of KRAS mutated tumors was highest in the cecum $(60 \%)$ [27, 28]. (Fig. 1a-c) The data emphasized the regional differences between proximal and distal CRCs with respect to clinicopathological and molecular pathogenesis [29]. In addition, we saw a bimodal distribution pattern in both male and female patients, which was different from Rosty et al. who showed that the frequencies of KRAS mutated carcinoma were diverse in different colorectal segments between male and female subjects [27]. Like CRCs with BRAF mutations, KRAS-mutated carcinomas had an increased frequency of the mucinous feature. Several others have also reported this finding $[27,30]$.

In the current study, we revealed that the $\mathrm{G}>\mathrm{A}$ transition, followed by $\mathrm{G}>\mathrm{T}$ transversion were the predominant types of KRAS mutations, and the substitution of aspartate for glycine at codon 12 was the most frequent change. Others have also identified the $\mathrm{G}>\mathrm{A}$ transition and the glycine to aspartate transition on codon 12 as the most frequent type of KRAS activating mutation [31-33]. For codon 13, the 38G > A transition was the most frequent type, which was similar to the findings of other studies [23, 34].

KRAS mutations were associated with a higher tumor stage (pT) in this study. However, there were no differences in risk of recurrence, DFS or OS in patients according to their KRAS mutation status. These findings are in agreement with those by Rosty et al.; however, the prognostic roles of KRAS mutations are still being debated [27, 34, 35]. 


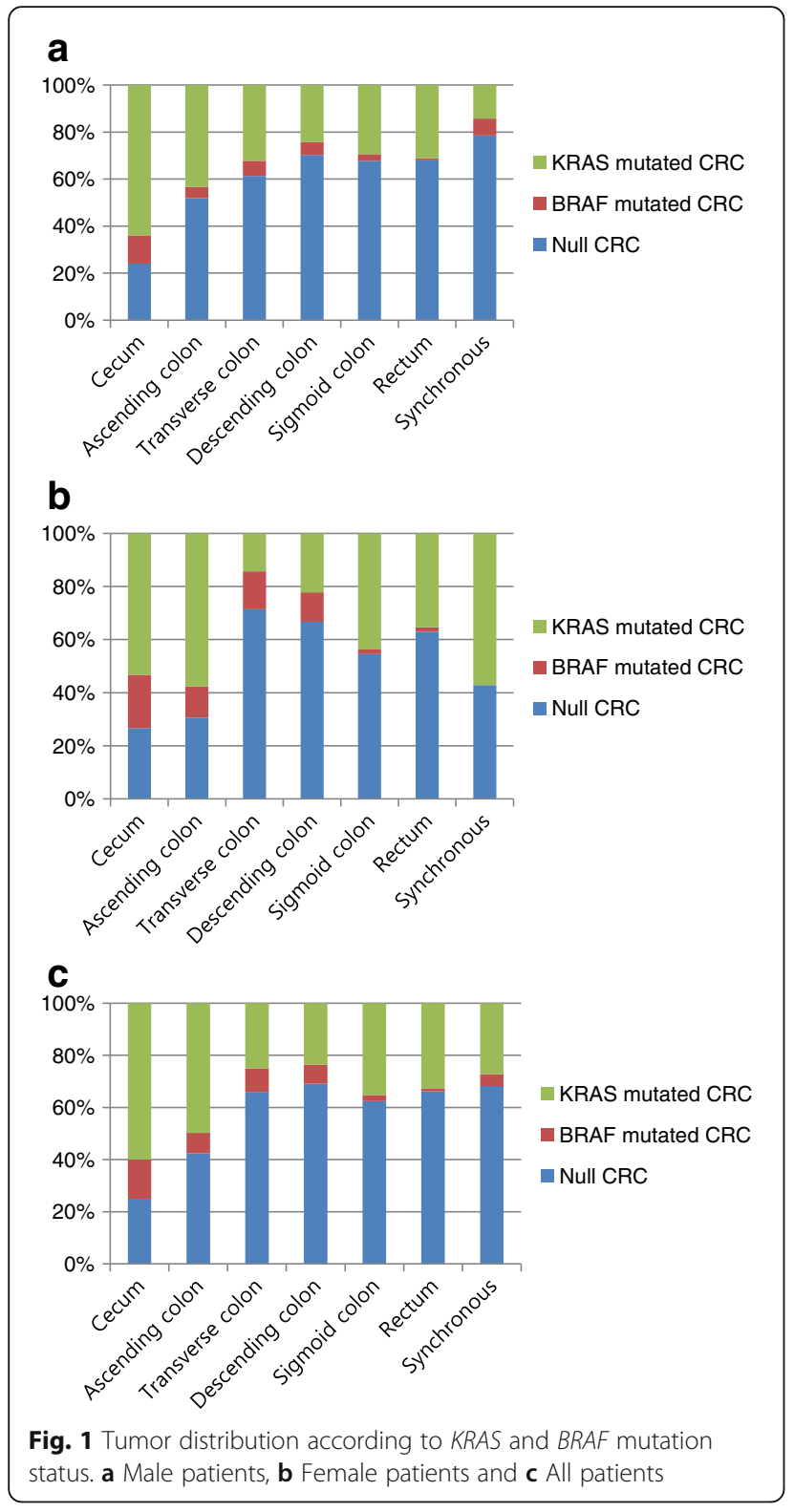

The reported frequency of $B R A F$ mutations in different populations varies widely. In this study, $B R A F$ mutations were found in $4.0 \%$ of colorectal cancers, which is slightly lower than previous reports worldwide (Table 6) [36-50]. In general, a lower incidence has been noted in Asian populations such as China, Japan, and Saudi Arabia [37-39]. Interestingly, two studies from Korea showed higher BRAF mutation rates of $15.9 \%$ and $9.6 \%$ $[40,41]$. The study cohort by Kim et al. consisted of advanced CRC patients, which might have influenced the higher mutation rate in their study [41]. Ahn et al. used the PNA-clamp real-time PCR method for the detection of $B R A F$ mutations, which is known to be superior to direct sequencing in sensitivity and might have caused
Table 3 Frequency of Mutations in KRAS exon2

\begin{tabular}{lll}
\hline KRAS codon 12 & & 16 \\
\hline c.34G > A & Gly12Ser & 2 \\
c.34G > C & Gly12Arg & 31 \\
c.34G > T & Gly12Cys & 148 \\
C.35G > A & Gly12Asp & 1 \\
c.35G > T & Gly12Asp & 88 \\
c.35G > T & Gly12Val & 5 \\
c.38G > A & Gly12Asp & 11 \\
c.35G > C & Gly12Ala & \\
KRAS codon 13 & & 1 \\
c.35G > A & Gly13Asp & 97 \\
c.38G > A & Gly13Asp & 2 \\
c.37G > T & Gly13Cys & 2 \\
c.36G > T & Gly13Val & 1 \\
c.38_39 GC > T & Gly13Val & \\
KRAS codon 14 & & 1 \\
c.40G > A & Val14lle & \\
KRAS codon 30 & & \\
c.90C > T & Asp30Asp & \\
\hline
\end{tabular}

differences in the mutation rate among study groups $[40,51]$. In addition, the enrolled patients of the study by Tsai et al. were under 30 years of age and distinct from other studies [47].

In this study cohort, we revealed that $B R A F$ mutation was significantly associated with poorer DFS and OS in colorectal cancers. In addition, $B R A F$ mutational status was an independent prognostic factor for DFS and OS in multivariate analysis, which is consistent with previous studies (Table 5). Moreover, we compared different tumor stages and found that BRAF mutations were also associated with poorer DFS and OS in both stage I and stage II/III subgroups. However, there was no significant association between $B R A F$ mutation and survival in the stage IV subgroup. Yaeger et al. recently showed that $B R A F$ mutation confers a poor prognosis in metastatic CRC patients [42]. This discrepancy may come from the relatively small study population in this metastatic setting, ethnic distinctions and subsequent differences in $B R A F$ mutation rates. Further studies in a larger population data are needed to confirm this result. Nevertheless, our findings highlight that the clinical meaning of $B R A F$ mutation is similar to Korean CRC patients, even if the

Table 4 Frequency of BRAF Mutations

\begin{tabular}{lll}
\hline BRAF codon 600 & & \\
\hline c.1799 T > A & Val600Glu & 43 \\
c.1796 C > G & Thr599Arg & 1 \\
\hline
\end{tabular}



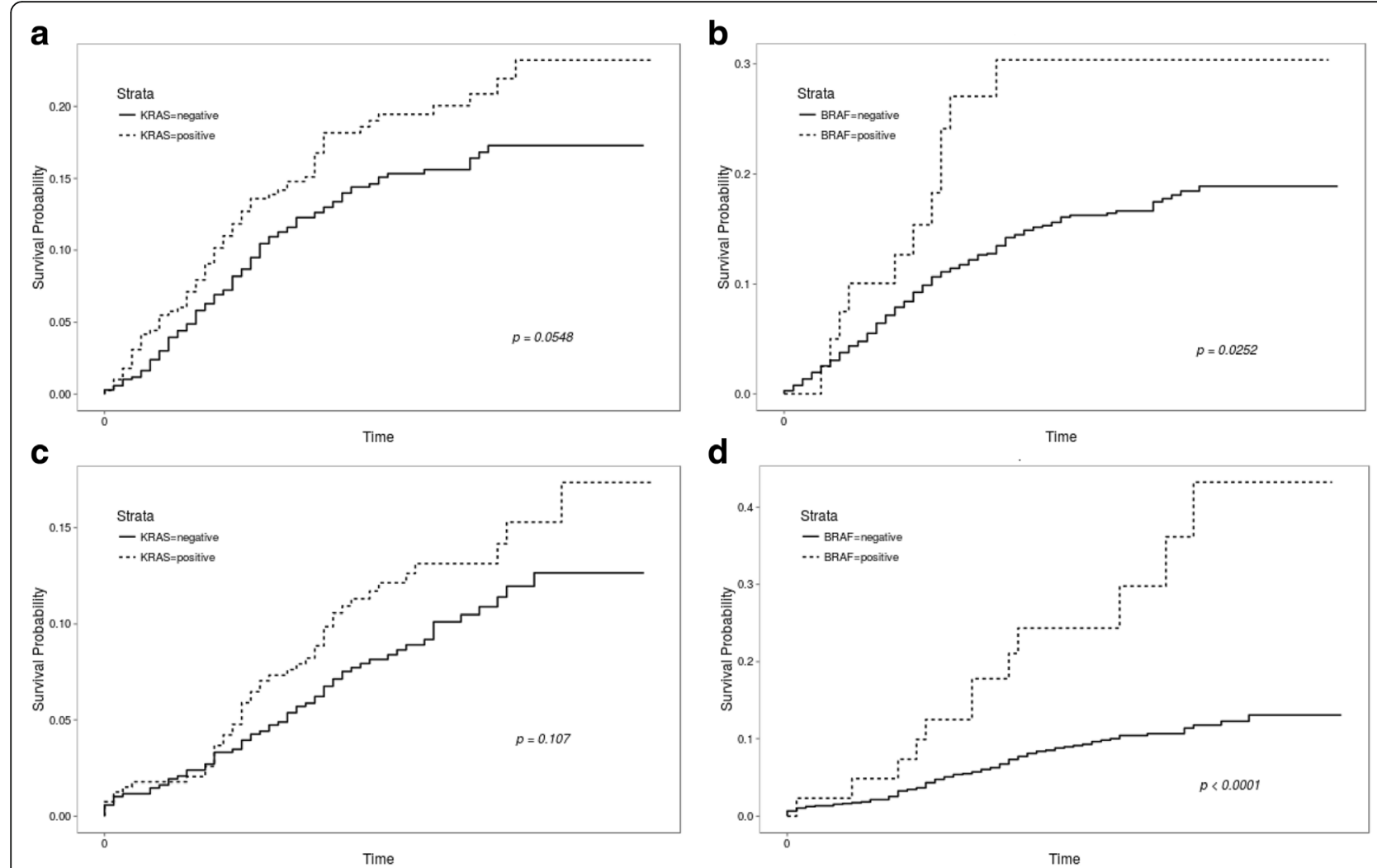

Fig. 2 Kaplan-Meier curves for disease-free survival and overall survival according to KRAS or BRAF mutation status. a Disease-free survival (DFS) according to KRAS status, b DFS according to BRAF status, c Overall survival (OS) according to KRAS status and $\mathbf{d}$ OS according to BRAF status

mutation frequency is lower than in western patients. Importantly, we revealed that $B R A F$ mutation status is important in predicting the prognosis of early CRCs, which is one of the novel findings of our study. Our findings support a role for BRAF mutation in the natural history of CRC because only rare cases in our study cohort received targeted therapy other than the standard chemotherapy regimen after resection.

We found that only $0.3 \%(n=3)$ of KRAS mutated CRC cases harbored BRAF mutations. Of these, two cases showed KRAS mutations at codon $13(38 \mathrm{G}>\mathrm{A})$ with the remaining mutation at codon $12(35 \mathrm{G}>\mathrm{A})$,
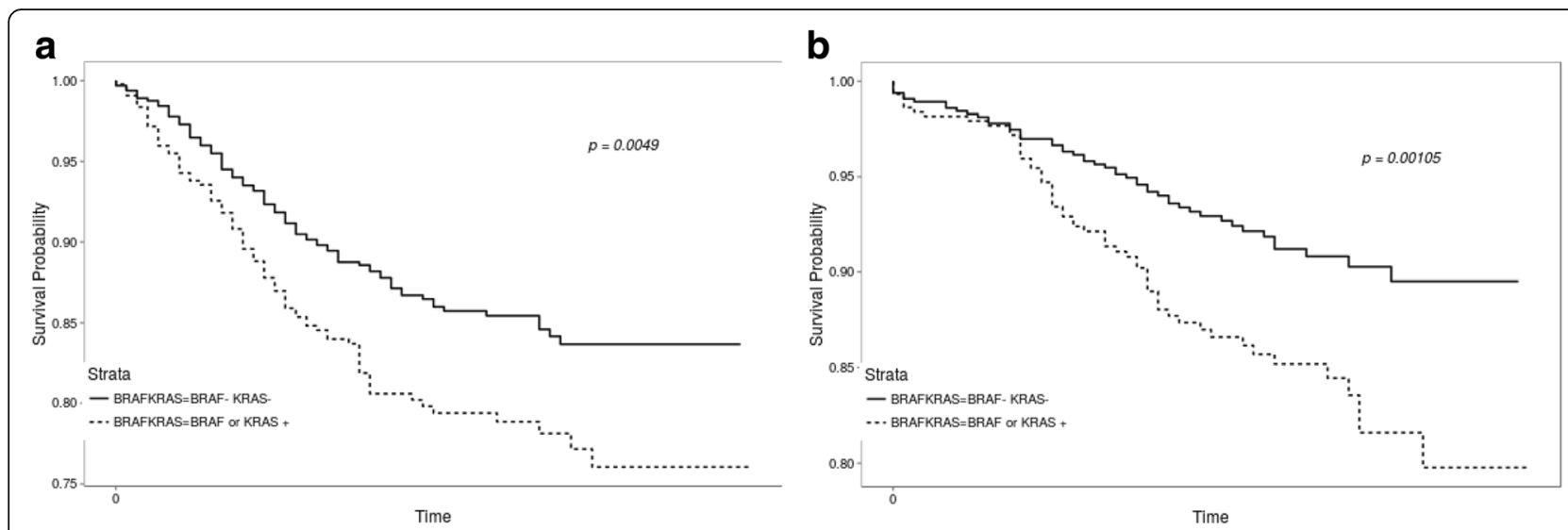

Fig. 3 Kaplan-Meier curves for DFS and OS according to KRAS mutation status in combination with BRAF. a DFS according to KRAS mutation status in combination with BRAF and $\mathbf{b}$ OS according to KRAS mutation status in combination with BRAF 

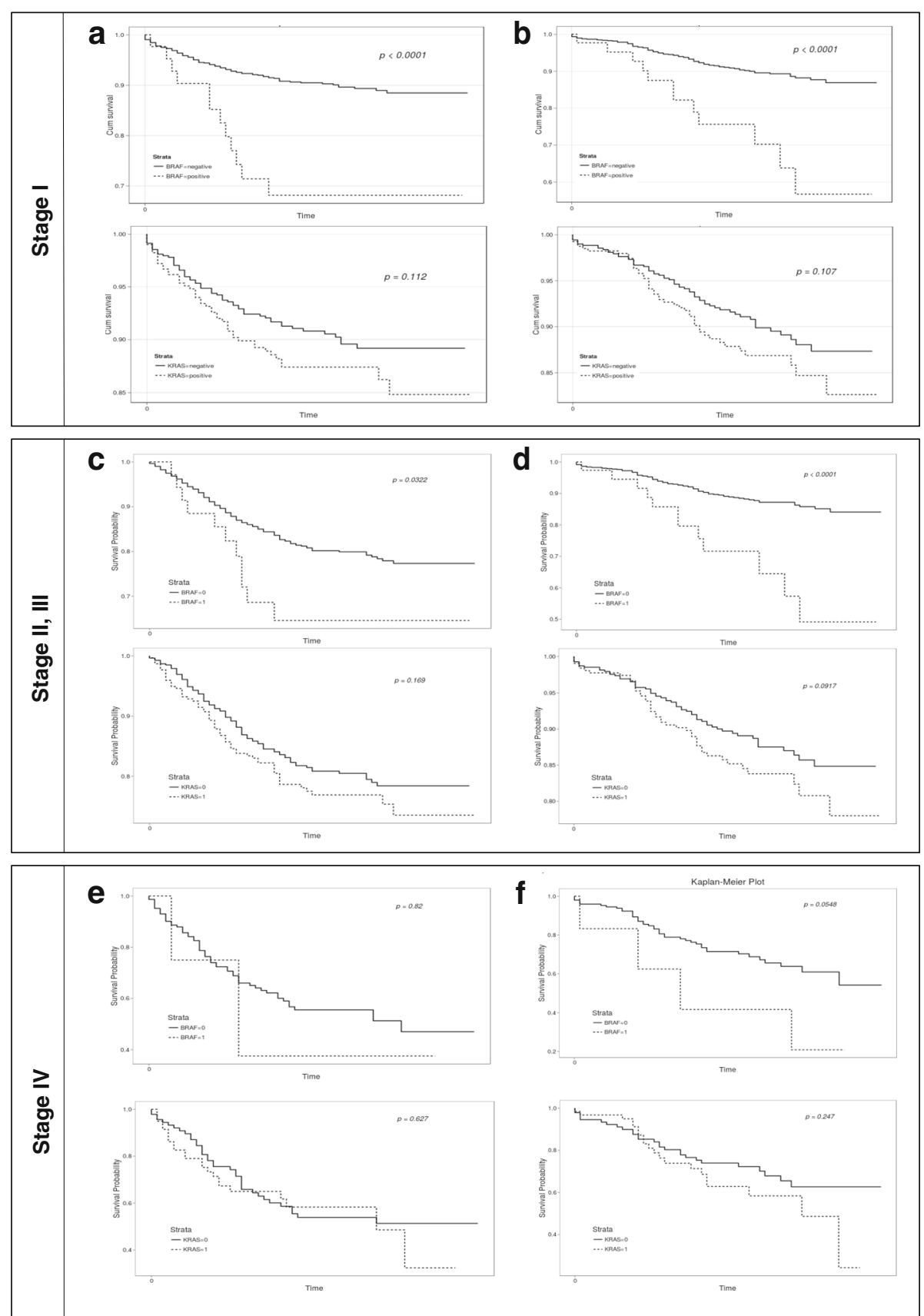

Fig. 4 Kaplan-Meier curves for DFS and OS according to KRAS or BRAF status in CRC patients with different stage. a DFS according to KRAS or BRAF status in CRC patients with stage I, $\mathbf{b}$ OS according to KRAS or BRAF status in CRC patients with stage I, $\mathbf{c}$ DFS according to KRAS or BRAF status in CRC patients with stage II and III, d OS according to KRAS or BRAF status in CRC patients with stage II and III, e DFS according to KRAS or BRAF status in CRC patients with stage IV and $\mathbf{f}$ OS according to KRAS or BRAF status in CRC patients with stage IV

and all three cases had the BRAF V600E mutation. The concomitant occurrence of KRAS and BRAF mutations is very rare in CRCs $(<1 \%)$, which imply tha they may play a role in different tumor subtypes $[11,52]$.

We analyzed the MSI status in 83 CRC patients and revealed a frequency of $7.2 \%$ for $\mathrm{MSI}-\mathrm{H}$, which appears somewhat lower than reports from western countries [53]. In line with our findings, a recent multicenter study by $\mathrm{Oh}$ et al. showed low frequencies of MSI-H in Korean CRC patients [53]. This result suggested ethnic differences in the molecular characteristics of colorectal tumorigenesis including MSI status. MSI is known to be associated with better 
Table 5 Clinicopathologic characteristics according to MSI status

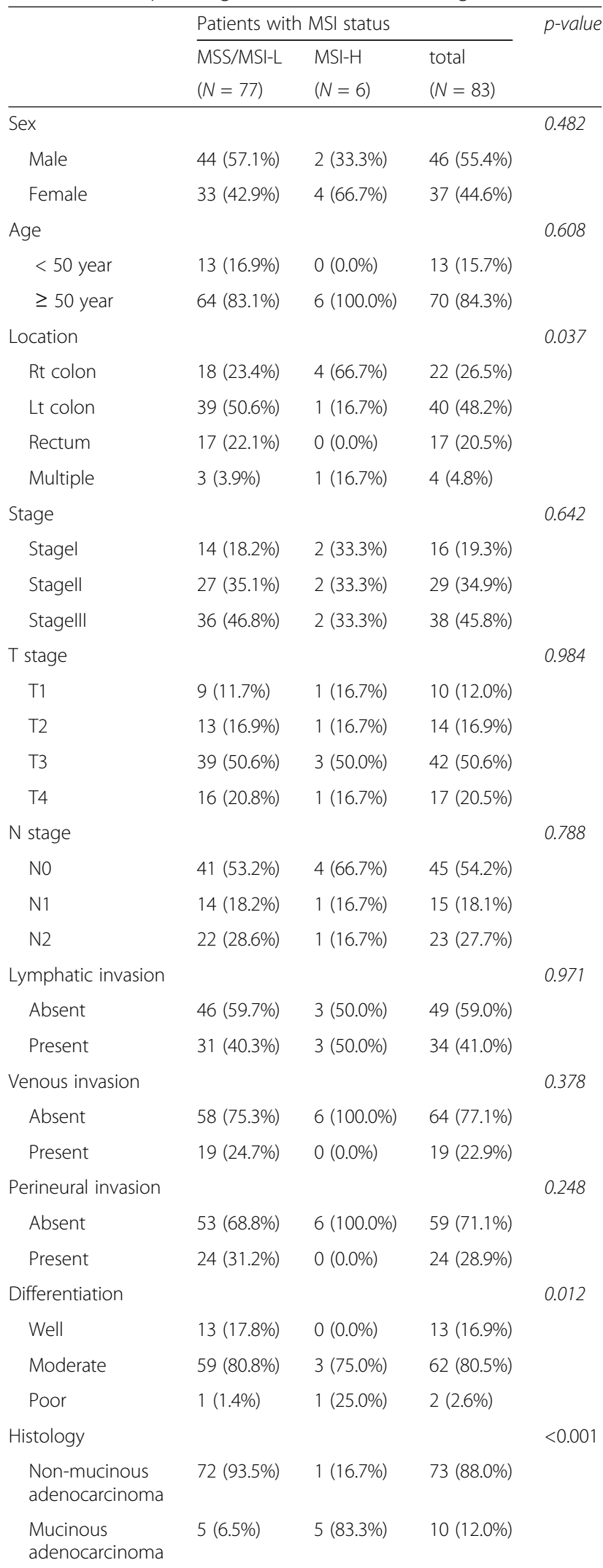

Table 5 Clinicopathologic characteristics according to MSI status (Continued)

\begin{tabular}{lllll}
\hline Recur & & & \multicolumn{2}{r}{0.608} \\
$\quad$ Recur & $64(83.1 \%)$ & $6(100.0 \%)$ & $70(84.3 \%)$ & \\
$\quad$ Non-recur & $13(16.9 \%)$ & $0(0.0 \%)$ & $13(15.7 \%)$ & \\
$\begin{array}{l}\text { Expire } \\
\text { Expire }\end{array}$ & $71(92.2 \%)$ & $6(100.0 \%)$ & $77(92.8 \%)$ & \\
$\quad$ Non-Expire & $6(7.8 \%)$ & $0(0.0 \%)$ & $6(7.2 \%)$ & \\
BRAF status & & & & 0.326 \\
Wild type & $76(98.7 \%)$ & $5(83.3 \%)$ & $81(97.6 \%)$ & \\
Mutation & $1(1.3 \%)$ & $1(16.7 \%)$ & $2(2.4 \%)$ & \\
KRAS status & & & & 0.102 \\
Wild type & $44(57.1 \%)$ & $6(100.0 \%)$ & $50(60.2 \%)$ & \\
Mutation & $33(42.9 \%)$ & $0(0.0 \%)$ & $33(39.8 \%)$ & \\
\hline
\end{tabular}

clinical outcome in early stage CRCs than MSS cancers [54, 55]. In the present study, MSI status did not have significant prognostic value on DFS and OS; however, a tendency toward worse survival was observed in MSS and MSI-L cases.

$B R A F$ activating mutations correlated with poor survival in MSS CRC. BRAF mutations occur in about $40 \%$ of MSI CRCs; however, it was unclear if it had a prognostic impact in this setting [45]. A recent study revealed that both $B R A F$ and KRAS mutations are associated with poorer survival in MSI CRC patients compared to those with wild-type BRAF and KRAS genes [45]. However, we could not draw any meaningful conclusion about the $B R A F$ and/or KRAS status in MSI CRC cohorts because the mutated cases in this study were rare.

A limitation of this study is the insufficiency of data on the efficacy of an EGFR-blocking antibody according to KRAS and BRAF mutation status due to only rare cases being treated by EGFR targeted therapy at our institution during the study period. In addition, the sample size was too small to evaluate the significance of the MSI status with infrequent KRAS and BRAF mutation subtypes. Subsequent translational studies from different cohorts are needed to confirm our data. Nevertheless, a strong point of this study is the relative large study cohort which reduce selection bias. We revealed $B R A F$ mutation as an independent prognostic marker for CRCs throughout all stages.

\section{Conclusion}

In conclusion, our study demonstrated that BRAF mutation, occurring at a low frequency, was a significant prognostic factor in Korean CRC patients. Our data suggests that molecular features that include $K R A S$ and $B R A F$ mutations as well as MSI status in CRC patients are 

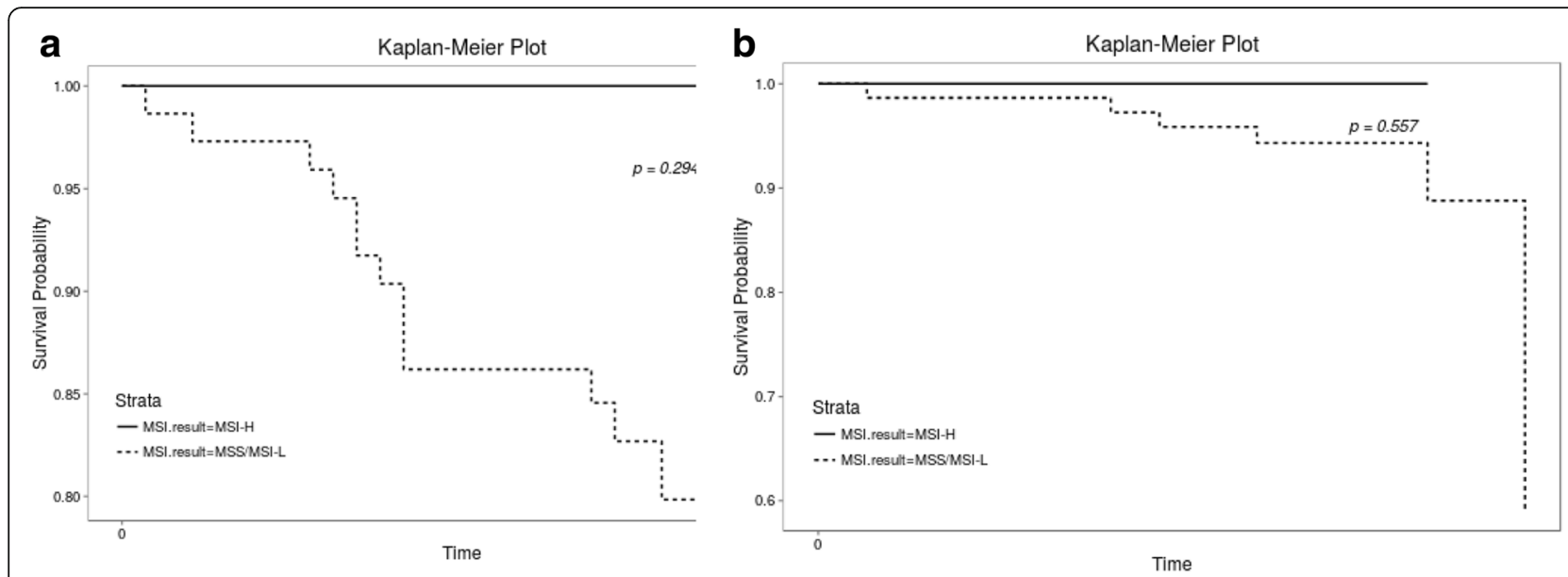

Fig. 5 Kaplan-Meier curves for DFS and OS according to MSI status. a DFS according to MSI status and $\mathbf{b}$ OS according to MSI status

Table 6 Studies on BRAF mutation status in colorectal cancer patients

\begin{tabular}{|c|c|c|c|c|c|c|}
\hline $\begin{array}{l}\text { Reference } \\
\text { (year) }\end{array}$ & Country & $\begin{array}{l}\text { BRAF mutation } \\
\%(\mathrm{n})\end{array}$ & $\begin{array}{l}\text { BRAF mutation } \\
\text { type (\%) }\end{array}$ & Methods & $\begin{array}{l}\text { Prognostic } \\
\text { value }\end{array}$ & Comments \\
\hline $\begin{array}{l}\text { Pai et al. } \\
\text { (2012) [36] }\end{array}$ & USA & $11.0(20)$ & V600E (100) & real-time $P C R$ & Significant & $\begin{array}{l}\text { Stage I-IV proficient } \\
\text { DNA mismatch repair }\end{array}$ \\
\hline $\begin{array}{l}\text { Kadowaki et al. } \\
\text { (2015) [37] }\end{array}$ & Japan & $4.9(40)$ & V600E (80) & $\begin{array}{l}\text { PCR combined with } \\
\text { restriction enzyme } \\
\text { digestion }\end{array}$ & Significant & $\begin{array}{l}\text { Stage I-III independent } \\
\text { of MSI status }\end{array}$ \\
\hline $\begin{array}{l}\text { Chen et al. } \\
\text { (2014) [38] }\end{array}$ & China & $4.2(9)$ & V600E (88.9) & direct sequencing & Significant & Stage I-IV \\
\hline $\begin{array}{l}\text { Siraj et al. } \\
\text { (2014) [39] }\end{array}$ & $\begin{array}{l}\text { Saudi } \\
\text { Arabia }\end{array}$ & $2.5(19)$ & V600E (89.5) & direct sequencing & $\begin{array}{l}\text { No prognostic } \\
\text { significance }\end{array}$ & Stage I-IV \\
\hline $\begin{array}{l}\text { Ahn et al. } \\
\text { (2014) [40] }\end{array}$ & Korea & $15.9(26)$ & V600E (100) & PNA clamp real-time PCR & Significant & Stage I-IV \\
\hline $\begin{array}{l}\text { Kim et al. } \\
\text { (2014) [41] }\end{array}$ & Korea & $9.6(13)$ & N/A & direct sequencing & Significant & Stage III-IV \\
\hline $\begin{array}{l}\text { Yaeger et al. } \\
\text { (2014) [42] }\end{array}$ & USA & $5(92)$ & V600E (96.7) & $\begin{array}{l}\text { mass spectrometry-based } \\
\text { assay }\end{array}$ & Significant & $\begin{array}{l}\text { Metastatic colorectal } \\
\text { cancers }\end{array}$ \\
\hline $\begin{array}{l}\text { Eklof et al. } \\
\text { (2013) [43] }\end{array}$ & Sweden & $\begin{array}{l}17.9(35) \\
13.2(54)\end{array}$ & V600E (100) & $\begin{array}{l}\text { allelic discrimination } \\
\text { assay }\end{array}$ & $\begin{array}{l}\text { Significant No } \\
\text { prognostic significance }\end{array}$ & $\begin{array}{l}\text { Stage I-IV two different } \\
\text { cohorts }\end{array}$ \\
\hline $\begin{array}{l}\text { Renaud et al. } \\
\text { (2015) [44] }\end{array}$ & France & $10.6(19)$ & V600E (100) & direct sequencing & Significant & $\begin{array}{l}\text { Metachronous lung } \\
\text { metastasis }\end{array}$ \\
\hline $\begin{array}{l}\text { de Cuba et al. } \\
\text { (2015) [45] }\end{array}$ & Netherlands & $51.0(73)$ & V600E (100) & $\begin{array}{l}\text { high resolution melting } \\
\text { and sequencing }\end{array}$ & Significant & $\begin{array}{l}\text { Stage II and III microsatellite } \\
\text { instable colon cancers }\end{array}$ \\
\hline $\begin{array}{l}\text { Foltran et al. } \\
\text { (2015) [46] }\end{array}$ & Italy & $5.2(10)$ & V600E (100) & pyrosequencing & Significant & $\begin{array}{l}\text { Metastatic colorectal } \\
\text { cancers }\end{array}$ \\
\hline $\begin{array}{l}\text { Tsai et al. } \\
\text { (2015) [47] }\end{array}$ & Taiwan & $18.6(11)$ & V600E (100) & direct sequencing & Significant & $\begin{array}{l}\text { Stage I-IV early-onset } \\
\text { colorectal cancers }\end{array}$ \\
\hline $\begin{array}{l}\text { Saridaki et al. } \\
\text { (2013) [48] }\end{array}$ & Greece & $8.2(41)$ & V600E (100) & real-time PCR & Significant & $\begin{array}{l}\text { Metastatic colorectal } \\
\text { cancers }\end{array}$ \\
\hline $\begin{array}{l}\text { Kalady et al. } \\
\text { (2012) [49] }\end{array}$ & USA & $11.7(56)$ & V600E (98.2) & direct sequencing & Significant & Stage I-IV \\
\hline $\begin{array}{l}\text { Farina-Sarasqueta } \\
\text { et al. (2010) [50] }\end{array}$ & Netherlands & $19.9(59)$ & V600E (100) & real-time $P C R$ & Significant & $\begin{array}{l}\text { Stage II and III independently } \\
\text { of disease stage and therapy. }\end{array}$ \\
\hline Present case & Korea & $4.0(44)$ & V600E (97.7) & direct sequencing & Significant & $\begin{array}{l}\text { Stage I-IV Significant prognostic } \\
\text { implications through all stages }\end{array}$ \\
\hline
\end{tabular}


important in future clinical trials. Further large translational studies are required to validate the significance of both $B R A F$ and/or KRAS mutation status in MSI CRCs.

\section{Additional files}

Additional file 1: Fig. S1. Kaplan-Meier curves for DFS and OS between KRAS mutation at codon 12 and 13. A. DFS between KRAS mutation at codon 12 and 13 and B. OS between KRAS mutation at codon 12 and 13. (PPTX $266 \mathrm{~kb}$ )

\section{Abbreviations}

BRAF: v-Raf murine sarcoma viral oncogene homolog B1; Cl: Confidence interval; CRC: Colorectal cancer; DFS: Disease free survival; EGFR: Epidermal growth factor receptor; FFPE: Formalin-fixed paraffin-embedded; KRAS: v-Kiras2 Kirsten rat sarcoma viral oncogene homolog; MAPK: Mitogen-activated protein kinase; MSI: Microsatellite instability; OS: Overall survival

\section{Acknowledgements}

The authors thank all patients who agreed to participate in this study

\section{Funding}

No specific funding was received for this study.

\section{Availability of data and materials}

The dataset presented in this investigation is available by request from the corresponding author.

\section{Authors' contributions}

SHL conceptualized and designed this study. DDW collected the clinicopathologic data and performed the data analysis. SHL and DDW interpreted the analysis results and drafted the manuscript. DDW, JIL, IKL, STO, ESJ, SHL were involved in revising the manuscript and providing critical reviews. All authors read and approved the final manuscript.

\section{Competing interests}

The authors declare that they have no competing interests.

\section{Consent for publication}

Not applicable.

\section{Ethics approval and consent to participate}

This study was approved by the Institutional Review Board of the Catholic University of Korea, Seoul St. Mary's Hospital, College of Medicine (KC16RISI0011) and written informed consent was obtained by all patients.

\section{Publisher's Note}

Springer Nature remains neutral with regard to jurisdictional claims in published maps and institutional affiliations.

\section{Author details}

'Department of Surgery, Seoul St. Mary's Hospital, College of Medicine, The Catholic University of Korea, Seoul, Republic of Korea. ${ }^{2}$ Department of Surgery, Uijeongbu St. Mary's Hospital, College of Medicine, The Catholic University of Korea, Seoul, Republic of Korea. ${ }^{3}$ Department of Hospital Pathology, Seoul St. Mary's Hospital, College of Medicine, The Catholic University of Korea, 222, Banpo-daero, Seocho-gu, Seoul 06591, Republic of Korea.

Received: 21 January 2017 Accepted: 22 May 2017

Published online: 05 June 2017

\section{References}

1. Jemal A, Bray F, Center MM, Ferlay J, Ward E, Forman D. Global cancer statistics. CA Cancer J Clin. 2011;61:69-90.

2. Shin A, Kim KZ, Jung KW, Park S, Won YJ, Kim J, et al. Increasing trend of colorectal cancer incidence in Korea, 1999-2009. Cancer res Treat. 2012;44:219-26.

3. Jung KW, Won YJ, Oh CM, Kong HJ, Cho H, Lee DH, et al. Prediction of cancer incidence and mortality in Korea, 2015. Cancer res Treat. 2015;47:142-8.
4. Cancer Genome Atlas N. Comprehensive molecular characterization of human colon and rectal cancer. Nature. 2012;487:330-7.

5. Arrington AK, Heinrich EL, Lee W, Duldulao M, Patel S, Sanchez J, et al. Prognostic and predictive roles of KRAS mutation in colorectal cancer. Int J Mol Sci. 2012;13:12153-68.

6. Poulogiannis G, Luo F, Arends MJ. RAS signalling in the colorectum in health and disease. Cell Commun Adhes. 2012;19:1-9.

7. Naguib A, Wilson CH, Adams DJ, Arends MJ. Activation of K-RAS by comutation of codons 19 and 20 is transforming. J Mol Signal. 2011;6:2.

8. Tran NH, Cavalcante LL, Lubner SJ, Mulkerin DL, LoConte NK, Clipson L, et al. Precision medicine in colorectal cancer: the molecular profile alters treatment strategies. Ther Adv med Oncol. 2015;7:252-62.

9. Tanaka M, Omura K, Watanabe Y, Oda Y, Nakanishi I. Prognostic factors of colorectal cancer: K-ras mutation, overexpression of the p53 protein, and cell proliferative activity. J Surg Oncol. 1994;57:57-64.

10. Dix BR, Robbins P, Soong R, Jenner D, House AK, lacopetta BJ. The common molecular genetic alterations in Dukes' B and C colorectal carcinomas are not short-term prognostic indicators of survival. Int J Cancer. 1994;59:747-51.

11. Roth AD, Tejpar S, Delorenzi M, Yan P. Fiocca R, Klingbiel D, et al. Prognostic role of KRAS and BRAF in stage II and III resected colon cancer: results of the translational study on the PETACC-3, EORTC 40993, SAKK 60-00 trial. J Clin Oncol. 2010;28:466-74.

12. Hutchins G, Southward K, Handley K, Magill L, Beaumont C, Stahlschmidt J, et al. Value of mismatch repair, KRAS, and BRAF mutations in predicting recurrence and benefits from chemotherapy in colorectal cancer. J Clin Oncol. 2011;29:1261-70

13. Hertzman Johansson C, Egyhazi BS. BRAF inhibitors in cancer therapy. Pharmacol Ther 2014:142:176-82

14. Montagut C, Settleman J. Targeting the RAF-MEK-ERK pathway in cancer therapy. Cancer Lett. 2009:283:125-34

15. Wan PT, Garnett MJ, Roe SM, Lee S, Niculescu-Duvaz D, Good VM, et al. Mechanism of activation of the RAF-ERK signaling pathway by oncogenic mutations of B-RAF. Cell. 2004;116:855-67.

16. Pietrantonio F, Petrelli F, Coinu A, Di Bartolomeo M, Borgonovo K, Maggi C, et al. Predictive role of BRAF mutations in patients with advanced colorectal cancer receiving cetuximab and panitumumab: a meta-analysis. Eur J Cancer. 2015;51:587-94.

17. Vaughn CP, Zobell SD, Furtado LV, Baker CL, Samowitz WS. Frequency of KRAS, BRAF, and NRAS mutations in colorectal cancer. Genes Chromosomes Cancer. 2011:50:307-12.

18. Davies H, Bignell GR, Cox C, Stephens P, Edkins S, Clegg S, et al. Mutations of the BRAF gene in human cancer. Nature. 2002:417:949-54.

19. Rowland A, Dias MM, Wiese MD, Kichenadasse G, McKinnon RA, Karapetis CS, et al. Meta-analysis of BRAF mutation as a predictive biomarker of benefit from anti-EGFR monoclonal antibody therapy for RAS wild-type metastatic colorectal cancer. Br J Cancer. 2015;112:1888-94.

20. Chen D, Huang JF, Liu K, Zhang LQ, Yang Z, Chuai ZR, et al. BRAFV600E mutation and its association with clinicopathological features of colorectal cancer: a systematic review and meta-analysis. PLoS One. 2014;9:e90607

21. Kim SY, Choi EJ, Yun JA, Jung ES, Oh ST, Kim JG, et al. Syndecan-1 expression is associated with tumor size and EGFR expression in colorectal carcinoma: a clinicopathological study of 230 cases. Int J med Sci. 2015;12:92-9.

22. Boland CR, Thibodeau SN, Hamilton SR, Sidransky D, Eshleman JR, Burt RW, et al. A National Cancer Institute workshop on microsatellite instability for cancer detection and familial predisposition: development of international criteria for the determination of microsatellite instability in colorectal cancer. Cancer res. 1998;58:5248-57.

23. Yoon HH, Tougeron D, Shi Q, Alberts SR, Mahoney MR, Nelson GD, et al. KRAS codon 12 and 13 mutations in relation to disease-free survival in BRAF-wild-type stage III colon cancers from an adjuvant chemotherapy trial (N0147 alliance). Clin Cancer res. 2014:20:3033-43.

24. Ye JX, Liu Y, Qin Y, Zhong HH, Yi WN, Shi XY. KRAS and BRAF gene mutations and DNA mismatch repair status in Chinese colorectal carcinoma patients. World J Gastroenterol. 2015;21:1595-605.

25. Herzig DO, Tsikitis VL. Molecular markers for colon diagnosis, prognosis and targeted therapy. J Surg Oncol. 2015;111:96-102

26. De Roock W, Claes B, Bernasconi D, De Schutter J, Biesmans B, Fountzilas G, et al. Effects of KRAS, BRAF, NRAS, and PIK3CA mutations on the efficacy of cetuximab plus chemotherapy in chemotherapy-refractory metastatic colorectal cancer: a retrospective consortium analysis. Lancet Oncol. 2010;11:753-62. 
27. Rosty C, Young JP, Walsh MD, Clendenning M, Walters RJ, Pearson S, et al. Colorectal carcinomas with KRAS mutation are associated with distinctive morphological and molecular features. Mod Pathol. 2013;26:825-34.

28. Yamauchi M, Morikawa T, Kuchiba A, Imamura Y, Qian ZR, Nishihara R, et al. Assessment of colorectal cancer molecular features along bowel subsites challenges the conception of distinct dichotomy of proximal versus distal colorectum. Gut. 2012;61:847-54.

29. Minoo P, Zlobec I, Peterson M, Terracciano L, Lugli A. Characterization of rectal, proximal and distal colon cancers based on clinicopathological, molecular and protein profiles. Int J Oncol. 2010;37:707-18.

30. Lin JK, Chang SC, Wang HS, Yang SH, Jiang JK, Chen WC, et al. Distinctive clinicopathological features of Ki-ras mutated colorectal cancers. J Surg Oncol. 2006;94:234-41

31. Andreyev HJ, Norman AR, Cunningham D, Oates JR, Clarke PA. Kirsten ras mutations in patients with colorectal cancer: the multicenter "RASCAL" study. J Natl Cancer Inst. 1998;90:675-84.

32. Adams R, Meade A, Wasan H, Griffiths G, Maughan T. Cetuximab therapy in first-line metastatic colorectal cancer and intermittent palliative chemotherapy: review of the COIN trial. Expert rev Anticancer Ther. 2008;8:1237-45.

33. Martinetti D, Costanzo R, Kadare S, Alimehmeti M, Colarossi C, Canzonieri V, et al. KRAS and BRAF mutational status in colon cancer from Albanian patients. Diagn Pathol. 2014;9:187.

34. Lee DW, Kim KJ, Han SW, Lee HJ, Rhee YY, Bae JM, et al. KRAS mutation is associated with worse prognosis in stage III or high-risk stage II colon cancer patients treated with adjuvant FOLFOX. Ann Surg Oncol. 2015;22:187-94.

35. Imamura Y, Morikawa T, Liao X, Lochhead P, Kuchiba A, Yamauchi M, et al. Specific mutations in KRAS codons 12 and 13, and patient prognosis in 1075 BRAF wild-type colorectal cancers. Clin Cancer res. 2012;18:4753-63.

36. Pai RK, Jayachandran P, Koong AC, Chang DT, Kwok S, Ma L, et al. BRAFmutated, microsatellite-stable adenocarcinoma of the proximal colon: an aggressive adenocarcinoma with poor survival, mucinous differentiation, and adverse morphologic features. Am J Surg Pathol. 2012;36:744-52.

37. Kadowaki S, Kakuta M, Takahashi S, Takahashi A, Arai Y, Nishimura Y, et al. Prognostic value of KRAS and BRAF mutations in curatively resected colorectal cancer. World J Gastroenterol. 2015;21:1275-83.

38. Chen J, Guo F, Shi X, Zhang L, Zhang A, Jin H, et al. BRAF V600E mutation and KRAS codon 13 mutations predict poor survival in Chinese colorectal cancer patients. BMC Cancer. 2014;14:802.

39. Siraj AK, Bu R, Prabhakaran S, Bavi P, Beg S, Al Hazmi M, et al. A very low incidence of BRAF mutations in middle eastern colorectal carcinoma. Mol Cancer. 2014;13:168.

40. Ahn TS, Jeong D, Son MW, Jung H, Park S, Kim H, et al. The BRAF mutation is associated with the prognosis in colorectal cancer. J Cancer res Clin Oncol. 2014;140:1863-71.

41. Kim B, Park SJ, Cheon JH, Kim TI, Kim WH, Hong SP. Clinical meaning of BRAF mutation in Korean patients with advanced colorectal cancer. World J Gastroenterol. 2014;20:4370-6.

42. Yaeger R, Cercek A, Chou JF, Sylvester BE, Kemeny NE, Hechtman JF, et al. BRAF mutation predicts for poor outcomes after metastasectomy in patients with metastatic colorectal cancer. Cancer. 2014;120:2316-24.

43. Eklof V, Wikberg ML, Edin S, Dahlin AM, Jonsson BA, Oberg A, et al. The prognostic role of KRAS, BRAF, PIK3CA and PTEN in colorectal cancer. Br J Cancer. 2013;108:2153-63.

44. Renaud S, Romain B, Falcoz PE, Olland A, Santelmo N, Brigand C, et al. KRAS and BRAF mutations are prognostic biomarkers in patients undergoing lung metastasectomy of colorectal cancer. Br J Cancer. 2015;112:720-8.

45. de Cuba EM, Snaebjornsson P. Heideman DA, van Grieken NC. Fijneman RJ, et al. Prognostic value of BRAF and KRAS mutation status in stage ॥ and III microsatellite instable colon cancers. Int J Cancer: Bosch L; 2015.

46. Foltran L, De Maglio G, Pella N, Ermacora P, Aprile G, Masiero E, et al. Prognostic role of KRAS, NRAS, BRAF and PIK3CA mutations in advanced colorectal cancer. Future Oncol. 2015;11:629-40.

47. Tsai JH, Liau JY, Lin YL, Tseng LH, Lin LI, Yeh KH, et al. Frequent BRAF mutation in early-onset colorectal cancer in Taiwan: association with distinct clinicopathological and molecular features and poor clinical outcome. J Clin Pathol. 2015;

48. Saridaki Z, Tzardi M, Sfakianaki M, Papadaki C, Voutsina A, Kalykaki A, et al. BRAFV600E mutation analysis in patients with metastatic colorectal cancer (mCRC) in daily clinical practice: correlations with clinical characteristics, and its impact on patients' outcome. PLoS One. 2013;8:e84604.
49. Kalady MF, Dejulius KL, Sanchez JA, Jarrar A, Liu X, Manilich E, et al. BRAF mutations in colorectal cancer are associated with distinct clinical characteristics and worse prognosis. Dis Colon rectum. 2012;55:128-33.

50. Farina-Sarasqueta A, van Lijnschoten G, Moerland E, Creemers GJ, Lemmens VE, Rutten HJ, et al. The BRAF V600E mutation is an independent prognostic factor for survival in stage II and stage III colon cancer patients. Ann Oncol. 2010;21:2396-402

51. Kobunai T, Watanabe T, Yamamoto Y, Eshima K. The frequency of KRAS mutation detection in human colon carcinoma is influenced by the sensitivity of assay methodology: a comparison between direct sequencing and real-time PCR. Biochem Biophys res Commun. 2010;395:158-62.

52. Phipps Al, Buchanan DD, Makar KW, Win AK, Baron JA, Lindor NM, et al. KRAS-mutation status in relation to colorectal cancer survival: the joint impact of correlated tumour markers. Br J Cancer. 2013;108:1757-64.

53. Oh JR, Kim DW, Lee HS, Lee HE, Lee SM, Jang JH, et al. Microsatellite instability testing in Korean patients with colorectal cancer. Familial Cancer. 2012;11:459-66.

54. Merok MA, Ahlquist T, Royrvik EC, Tufteland KF, Hektoen M, Sjo OH, et al. Microsatellite instability has a positive prognostic impact on stage II colorectal cancer after complete resection: results from a large, consecutive Norwegian series. Ann Oncol. 2013;24:1274-82.

55. Sinicrope FA, Mahoney MR, Smyrk TC, Thibodeau SN, Warren RS, Bertagnolli MM, et al. Prognostic impact of deficient DNA mismatch repair in patients with stage III colon cancer from a randomized trial of FOLFOX-based adjuvant chemotherapy. J Clin Oncol. 2013;31:3664-72.

\section{Submit your next manuscript to BioMed Central and we will help you at every step:}

- We accept pre-submission inquiries

- Our selector tool helps you to find the most relevant journal

- We provide round the clock customer support

- Convenient online submission

- Thorough peer review

- Inclusion in PubMed and all major indexing services

- Maximum visibility for your research

Submit your manuscript at www.biomedcentral.com/submit
) Biomed Central 